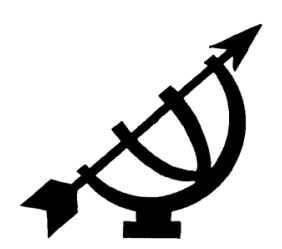

\title{
Law, religion and organ transplants
}

\author{
M. Slabbert \& F.D. Mnyongani \\ Department of Jurisprudence \\ Unisa \\ PRETORIA \\ E-mail: slabbm@unisa.ac.za \\ mnyonfd@unisa.ac.za
}

\author{
N. Goolam \\ Faculty of Law \\ Rhodes University \\ GRAHAMSTOWN \\ E-mail: N.Goolam@ru.ac.za
}

\section{Abstract \\ Law, religion and organ transplants}

Currently any organ donation in South Africa, whether from a living or a dead donor, is donated altruistically, which means that it is the free choice of the donor or the family of the deceased to donate organs. There is no financial compensation for the donor. Nearly all religions support altruistic organ donations as it serves or promotes life. But, despite the positive attitude of the followers of different faiths towards organ transplantations, there is a worldwide shortage of transplantable organs, especially kidneys. Many patients die while waiting for a transplant organ from an altruistic donor. The question may therefore be asked whether the different religions should not also support the clamouring for the financial rewarding of an organ donor. In this article the emphasis is on the Christian and Muslim faiths to try and fathom their position in this regard. In conclusion, however, we argue that financial compensation to donors, as a general practice, should be allowed irrespective of religious arguments, as the decision to donate altruistically or to receive compensation is an expression of personal autonomy.

\section{Opsomming}

\section{Die reg, geloof en orgaanskenkings}

Enige orgaanskenking in Suid-Afrika, hetsy 'n skenking van 'n lewende of 'n afgestorwe skenker, word tans op altruïstiese 
gronde gedoen. Dit beteken dit is die keuse van die skenker of die familie van die oorledene om 'n orgaan te skenk of nie. Daar is geen finansiële vergoeding vir die skenker nie. Byna alle gelowe regverdig altruïstiese orgaanskenkings, omdat dit lewens kan red en lewensgehalte kan verbeter. Ten spyte van die positiewe houding van die navolgers van verskeie gelowe ten opsigte van orgaanoorplantings, is daar steeds 'n wêreldwye tekort aan oorplantbare organe, veral niere. Baie pasiënte sterf terwyl hulle op 'n oorplanting wag. Die vraag kan daarom tereg gevra word of die verskillende gelowe nie die aandrang om finansiële vergoeding vir skenkers behoort te steun nie. In hierdie artikel val die klem op die Christen- en Moslemgelowe om hulle posisie in hierdie verband te probeer peil. Daar word tot die slotsom gekom dat 'n praktyk wat vergoeding aan skenkers toelaat moontlik moet wees, afgesien van godsdienstige beskouings daaroor, aangesien orgaanskenking 'n uitdrukking van persoonlike outonomiteit is. Dit is die uitdrukking van selfbeskikking wat aan 'n persoon die reg gee om self te besluit of hy/sy 'n orgaan altruïsties wil skenk of daarvoor vergoed wil word.

\section{Introduction}

Medical practitioners have always been confronted with the challenge of not only healing patients, but also of prolonging life. As a result of intensive research and blood experimentation, different blood types were identified and risks associated with blood transfusions decreased considerably. Based on the success with blood transfusions, doctors started to consider the possibility of replacing defective human organs with healthy organs from deceased persons (cadavers). They surgically removed an organ from a brain dead1 person and replaced it in a patient to improve the health of the recipient. Today, after years of experimentation, not only cadavers but also living donors are used. 2 Currently any donation, whether it is from a living or a deceased donor, is done altruistically, which means it is the choice of the donor or his/her family to donate organs or not, and there is no financial compensation for the donor (or donor's family).

1 This article will not address the different religious views on brain death. For a discussion on brain death, see Ott (1998:16-23).

2 Most living donors donate a kidney, although parts of a liver lobe can also be transplanted from a living donor. This article will focus on kidneys. 
Most, if not all, religions accept altruistic organ donations and justify it because it saves and promotes life. But, despite the positive attitude of the followers of different faiths towards organ transplantations and altruistic donations, there is an immense global shortage of transplantable organs, specifically kidneys. Because the supply cannot satisfy the demand, illegal activities might and are in fact taking place between a willing buyer (the patient) and a person who needs money and is willing to sell his/her kidney (Liebenberg, 2010: 2). ${ }^{3}$ The question can, therefore, rightly be asked whether the different religions should not support the clamour for the financial rewarding of the donor. Rewarding donors financially could persuade more people to come forward as organ donors, and by doing so more lives could be saved, which is in line with the promotion of life.

In the first section of this article the focus will be on the present state of organ donations. We discuss different types of transplants, the shortage of transplantable organs globally, the legal context of organ transplantations in South Africa, and the fallacy of the "'gift of life"' view. We provide an abbreviation of a small sample of religious worldviews on altruistic donations and transplantations, and indicate that most religions do not address payment for donors, as the practice is illegal nearly worldwide (Garwood-Gowers, 1999:167194).

In the second part of this article, financial reward to donors as a possible way of addressing the kidney shortage will be investigated. The spotlight will be on the Christian and Islamic faiths, which constitute the two biggest religious groupings in the world. We will investigate the views of these two religious groups with regard to a donor who receives financial reward for donating an organ.

In conclusion, we argue that financial compensation to donors should be allowed in order to give effect to personal autonomy. Each individual ought to decide according to his/her values and belief system whether to donate a kidney altruistically or to be rewarded religious perceptions should not be a stumbling block.

3 Netcare 911, a private hospital group in South Africa, pleaded guilty in a court case accusing the St Augustine's Hospital (a Netcare hospital) in KwaZulu-Natal of performing illegal kidney transplants on Israeli patients, who alleged that persons from Brazil and Romania were their blood relatives but in reality were willing to sell a kidney (The State $v$ Netcare Kwa-Zulu Natal, 2010). 


\section{Background}

\subsection{Different types of transplantations}

There are four types of transplants that can be performed, namely auto grafts, isografts, homografts and xenografts. An auto graft refers to the transplanting of an organ or tissue, such as skin or bone marrow, of a particular person to a different part of the body of the same person. This type of transplantation poses no ethical or religious problems as the donor and recipient are one and the same person. Isografts keep transplants of organs or tissue between genetically identical individuals such as identical twins - the first ever kidney transplant was performed in this way, but because identical twins are not common, this type of transplant is more of an exception than a rule. Homografts are transplants kept in the same biological realm, in other words an individual donates an organ to another individual of the same species (person to person). Since this is the most common type of transplant, it will be the focus of this article. Finally, xenografts are transplants between different species - animal to human (Varga, 1980:140; Caplan \& Coelho, 1998:121132).

\subsection{From experiment to common procedure}

The first kidney transplant was performed in 1951 by David Hume in Boston. He used a cadaver kidney in an attempt to save the life of one of his patients but the attempt was unsuccessful (Varga, 1980: 142). During the following four years, Dr Hume and his colleagues performed ten further kidney transplants. Most patients died soon after the transplants, but one survived for six months. This success instilled in them the confidence to continue. The first kidney transplant regarded as a real success took place in 1954 and the organ was from a living donor. The recipient, who received an isograft from his twin brother, lived for eight years before dying of a heart attack (Varga, 1980:143-144).

Initially, the rejection of transplanted organs in homografts posed a big problem. Peter Medawar, an immunologist and Nobel Prize winner in 1960, contributed to the solution by advocating tissue typing on both the donor and the recipient before a transplant is performed to ensure that their tissues match. Doing this would prevent the recipients' body from identifying the transplanted organ as "foreign". If the transplanted organ is experienced as foreign the recipient's immune system will attack the "new" organ in order to try and break it down. This is know as rejection. A breakthrough came in 1983 
when a Swiss pharmaceutical company produced Cyclosporin which enables the body to suppress the rejection of foreign tissue selectively (Varga, 1980:144). Unrelated donor kidneys could from then on be used and using kidneys from living persons to save patients became a reality. The ability to control tissue and organ rejection changed kidney transplants from sporadic experimental interventions to nearly common practice. Even though kidney transplants are now nearly routine operations in many hospitals, the shortage of transplantable kidneys, however, prevents it from happening often enough.

\subsection{Organ shortages}

The shortage of transplantable organs cannot necessarily be linked to the system of organ procurement in a specific country, as no procuring system meets the demand. To procure organs the United States of America (Goodwin, 2006), the United Kingdom (Haddow, 2006:324-328) and South Africa, among others, follow a system of opting-in. Opting-in relies on individuals to altruistically donate organs voluntarily (Slabbert \& Oosthuizen, 2007b:311-312). A prospective donor indicates the wish to become a donor by signing a donor card (to be kept in the donor's purse) or by simply informing the next of kin about the decision to donate organs (Blackbeard, 2003:47-48). Unfortunately "the most significant aspect of this method of procuring transplant organs is its clear failure to secure anywhere near the number of organs that are required" (Goodwin, 2006:9-10, 39; cf. also Taylor, 2005:5).

In 2008 only 631 transplants (solid organs as well as corneas) were performed in South Africa, whereas approximately 3500 people were in need of a new organ. To meet the need, at least 1000 kidneys should be transplanted every year. But in 2007 and 2008 less than a quarter of these desperately needed transplants were performed. 4

As in the United Kingdom, health workers in South Africa always approach the family of a deceased person for their consent before removing the organs - even in cases where the patient carries a

$4 \quad$ The statistics are for both the public and the private health care sectors. There is no official national waiting list of patients waiting for a transplant in South Africa. The figures are therefore estimates. Statistics are available on the website of the Organ Donor Foundation - a non-governmental organisation in South Africa promoting organ donations (http://www.odf.org.za). 
donor card. Statistics show that if the family does not know how the deceased felt about an organ donation, 30\% will not consent to an organ removal (Haddow, 2006:324).

In 200486173 people were on the nation's organ transplant waiting list in the USA. Seventeen patients died every day while waiting for an organ, whereas 115 patients were added daily to the waiting list (Kishore, 2005:362). In 2006 more than 93000 patients needed an organ transplant, but only 14699 transplants were performed (Statz, 2006:1677-1678). Apart from the opting-in system, some states in America also follow a system known as required request (Slabbert \& Oosthuizen, 2007a:47). Through this way of organ procurement, every person when admitted to hospital is asked to become an organ donor. Despite the fact that both of these systems attempt to motivate people to become donors, there is still a dire need for transplantable organs and the demand far outnumbers the supply. "Those who can avoid America's transplantation system will do so. They will bypass the American waiting list process for greater access abroad, even if that choice involves paying a destitute living donor and violating the law." (Goodwin, 2006:6.)

The organ shortage is as critical in Europe. Austria, Belgium, Luxembourg, Germany, the Netherlands, and Slovenia form part of Euro Transplant, an organisation within the European Union which monitors organ transplant activities. In 2004 this organisation reported an organ shortage of 15585 . This shortage existed despite the fact that Belgium and Austria follow a system of opting-out (Taylor, 2005:24, footnote 23). According to this method of procuring organs, all citizens of a country are considered organ donors unless exclusion is requested before death. The trouble with this way of procuring organs is that it allows the state to take possession of a person's property 5 without consent, which might be seen as undermining personal autonomy (Taylor, 2005:23). The success of this way of procuring organs is also dependent on the availability of a national database that enables hospital staff to determine quickly whether a deceased person has indicated unwillingness to be an organ donor. It may be deduced that such a "compulsory" system does not make a substantial difference to the acute shortage of organs.

5 Property rights in human organs are a separate topic and cannot be dealt with in this article. For a discussion on this topic see Slabbert (2009:499-517). 
Although statistics of only a few countries were highlighted, they clearly indicate both a near worldwide organ shortage and the failure of current organ procurement systems to provide an adequate number of transplantable organs. Another obstacle in procuring organs might be the existing legislation in a country. It is, therefore, necessary to look at the legislation in South Africa concerning organ transplantations.

\section{Legal aspects of organ transplants in South Africa}

The National Health Act, 61 of 2003 (South Africa, 2003) came into effect on 2 May 2005. Section 93(1) of this Act repeals the Human Tissue Act, 65 of 1983 in total, but this will take effect only on a date fixed by the president as published in a Government gazette. In the interim the Human Tissue Act, 65 of 1983 and the regulations issued in terms thereof, remain in force. It is thus necessary to look at both these acts concerning organ transplantations.

\subsection{The Human Tissue Act, 65 of 1983}

The Human Tissue Act, 65 of 1983 (South Africa, 1983) stipulates in section 2 that anyone competent to make a will (sixteen years or older) may donate an organ by signing a document attested to by two competent witnesses (fourteen years or older), or by indicating this wish through a clause in a will, or orally before two competent witnesses. In other words, it is up to the individual to indicate his/her wish to be an organ donor. This is done while the donor is still alive and compos mentis (having full control of one's mind), whereas the actual donation will take place only after death. In the absence of a donation made by a deceased before death, the Act stipulates that the deceased's spouse, major child, parent, guardian, major brother or major sister may donate usable organs of the deceased after death $(\mathrm{S} 2(2)(\mathrm{a}))$. In practice, this is what happens in almost every case, as hospital staff usually asks the relatives for a donation, irrespective of whether the deceased has indicated his/her willingness to be an organ donor. If the relatives of a deceased cannot be traced, the Director-General of the Department of Health or any person specifically authorised thereto, may, after all reasonable steps had been taken to locate the relevant family members, donate organs of the deceased (S2(2)(b)).

The moment of death is not addressed in the Human Tissue Act and the Act does not recognise brain stem death as death. The moment of death has a bearing on organ donations as all vital organs - the heart, lungs, kidneys and liver - may only be removed once a per- 
son is brain dead. Section 18 of the Act stipulates who may consent to an organ being harvested while still alive. Consent must be given in writing and in accordance with prescribed conditions.

In South Africa, donations from living persons are accepted only if they are related to the patient or the patient's spouse. If a friend or an altruistic donor wants to donate an organ, an application has to be lodged with the Department of Health. The Department will investigate the offer thoroughly, so as to determine that it is not for financial gain, as section 28 specifically prohibits any payment for donated human organs.

\subsection{The National Health Act, 61 of 2003}

Section 62 of the National Health Act, 61 of 2003 (South Africa, 2003) generally has the same requirements for an organ donation in the case of a deceased donor as the Human Tissue Act, 65 of 1983. The only difference of any note is that the new Act in section 1 acknowledges "brain death" as death. Section 55 addresses organ donations by living donors.

Section 60(4)(a) states that it is an offence for a person who has donated tissue to receive any form of financial or other reward for such donation, except for the "reimbursement of reasonable costs" incurred by him/her to provide such donation. The Act does not indicate what may be included as "reasonable costs". Singapore has recently passed the Human Organ Transplant Act with a similar stipulation. According to this act, costs that may be reimbursed include short- and long-term medical care, loss of income, travel, accommodation and child care costs (Gutierrez, 2009). Singapore's Minister of Health, Khaw Boon Wan, explained that the reason behind this is fairness - being fair to donors who suffer financial consequences as a result of their act of donation (Roth, 2009).

The Organ Donor Foundation (SA) promotes organ donations among the public usually by using the slogan: "Give someone the gift of life". The metaphor of "the gift of life" may aid public awareness campaigns but according to Siminoff and Chillag (1999:35) it does not help the actual donating process.

\section{The "gift of life"}

The ideal transplant scenario is to harvest organs from brain dead patients, since these patients are dead but kept alive artificially by machines. These dead people have no further use for any of their 
organs and if the necessary consent required by law is granted, the organs may be used to save the lives of people or to improve their quality of life. Harvesting transplant organs under these conditions is less controversial, yet less effective as well. Many families approached at a time of grief refuse permission for removal of organs from the bodies of their loved ones. If they do agree to donate some or all organs it is usually in the hope that the deceased will somehow live on in others; or it is a way to express their desire to help others, especially so that the death of the deceased would accrue meaning to them; they seldom think of it as a "gift of life" (Siminoff \& Chillag, 1999:36).

As indicated earlier there is a dire need for transplantable organs, especially kidneys. A way of procuring enough kidneys to meet the full demand is by using unrelated living donors. Kidney recipients benefit significantly from living-donor organs. The one year survival period with a deceased-donor kidney is $94 \%$, but with a living-donor kidney survival rises to $98 \%$. Five year survival from a dead donor increases from $80 \%$ to $90 \%$ with a living donor. When a living donor is used, planning can be better, as the donor and the recipient are present. Living donors can be better screened for illnesses and immunological compatibility can be ensured (Munson, 2007:214).

Persons outside the family circle should, therefore, also be allowed to donate a kidney. As explained above, legislation in South Africa prescribes that living donors should be related to or at least be the spouse of the recipient. Offering a kidney in these circumstances seems heroic in that a family member offers his/her kidney to be transplanted as "a gift of life". But unfortunately in reality "... some of the so-called 'voluntary' related donors brought in by patients were very unwilling, but had been coerced into volunteering by other family members" (Kanniyakonil, 2009). If the law could be changed to allow unrelated living donors, and to reimburse their costs incurred with the donation as provided for in the new Act (61 of 2003), it will be a first step in the direction of a better dispensation.

Sque and Payne (1996:1367) suggest that "organ transplantation is sociologically and psychologically related to the dynamics of gift exchange, as monetary reimbursement for organs is outlawed in most developed countries". In contrast, Fox and Swazey (1992:33) point out that recipients often believe they owe the organ donor something. The psychological and moral burden to repay "their" donor then weighs heavily on them, especially since the "gift" they received is so extraordinary that it is inherently unreciprocal. 
Marshall et al. (1996:1-18) report meeting a man who received a kidney transplant in Madras, India. The donor came to his house to find out how he was doing. He (the recipient) wanted to know the same from the donor, whereupon the donor complained about severe pain. The recipient gave him money for medicine as he felt he had to help him because he saved his life. He even explained he would give him more money should he ask again. It thus seems that in many (perhaps most cases) a donor's altruistic gift became an obligatory burden to the recipient. Had the donor received a reasonable amount of money for his inconvenience from the start, such moral baggage would not have been necessary for the recipient to carry.

This view is supported by Radcliff-Richards (1991:190-193), who writes about a Turkish father who arranged to sell a kidney in order to pay for urgent hospital treatment for his little daughter. Because he was poor and desperate, selling a kidney was his only option this very fact shows how unspeakably bad his circumstances must have been. Because the selling of kidneys are forbidden, his only viable option was ruled out and he was prevented from saving two lives - his daughter's and that of the patient who would have bought his kidney. If his daughter needed a kidney transplant and he donated his kidney to her, he would have been a hero. RadcliffRichards correctly asks whether the real issue is not rather the poverty situation some people find themselves in, than the trade of kidneys.

The metaphor of "gift of life" suits those concerned with transplants and the community at large, because it is easy to understand and it fits into religious and cultural ideals about altruism (Siminoff \& Chillag, 1999:40). It appears as if everyone buys into the notion, yet when it comes to actually donating, people are not as generous as one would expect. Shouldn't religious communities, therefore, get more actively involved with the reality of organ shortages by advocating the advantages of organ transplants, instead of just supporting the emotional slogan, "gift of life"?

\section{Some religious views on altruistic organ donations}

It is necessary to take note of some religious views, as religion plays a very important role in people's behaviour and thus affects how they think about organ transplants and their reaction to organ donation. Only a few religious groupings' general views on transplantation will be highlighted to indicate their importance in the present context. We can expect there will be no specific views on 
rewarding a donor but from the general trends of thinking it may be possible to infer a position.

Buddhism (http://www.geocities.com/organdonate/religionculture andharvesting.html) view life as a continuum: after the conscious mind and brain processes have slipped into death, the spiritual process continues. Death is not seen as a disaster, but merely a change of consciousness. Therefore, removing a donor's organs and spending vast resources to fit these organs into another body to preserve life, appears to a Buddhist as an act of ego delusion, which may indicate ignorance of one's spiritual identity. Clarity of mind is crucial during the dying process as it determines the quality of one's next incarnation. Cutting open a donor's body might be disturbing during the evisceration process. Buddhists, therefore, do not condemn organ transplants but neither do they promote them.

Hindus (http://www.donatelifenm.org/religiousviews.htm) are not prohibited by their religious laws from donating their organs. It is an individual decision. There is nothing in the Hindu religion indicating that parts of humans, dead or alive, may not be used to alleviate the suffering of other humans. Most religious Indians are Hindu. The rites observed after death include burning the intact body in the presence of the family. Religious Indians, therefore, do not donate organs from cadavers. But religious rites are not the only reason why Indians do not donate their organs. India has a poor transport system, an extremely hot climate and a shortage of trained transplant surgeons - all of which are essential in organ procurement and transplanting processes (Kanniyakonil, 2009). Because their death rite results in a severe shortage of transplantable cadaver kidneys in India, living donors are mostly used and renders India an ideal target for black market activities (Slabbert, 2008:75-99). These illegal practises could be controlled if India follows the example of Iran.6

Desai (1988-1990:55) writes about "organ bazaars" in India procuring human organs for sale. He comes to the conclusion that all the parties benefit: the recipient gets a healthy organ that can prolong life, the donor gets monetary compensation and the hospital and physician receive their money. Yet he still feels regulation is necessary. He goes on to comment that if the future prospects of an

6 In Iran, a regulated system of payment for kidneys was instituted in 1988, which eliminated the renal transplantation waiting list. Most donors are living unrelated donors who receive a government donor award of health insurance, \$1200 (in 1988) and post-operative drugs and care (cf. Ghods \& Savaj, 2006:1136-1145). 
entire family are changed by the sale of an organ which brings in more money than the family might expect to earn in a lifetime, it is difficult to take a moral or legal stance against such a transaction. He concludes by saying that India and Hinduism need a reinterpretation of ancient wisdom in the context of changed realities.

The Japanese religion of Shinto has a religious doctrine directly against organ harvesting and transplantations. Such actions are considered spiritually dirty, and therefore organ transplants are almost non-existent in Japan. In 2000 just eight sets of kidneys were obtained from dead donors upon family consent. The downside of this approach is that Japanese patients become "organ tourists"; they travel overseas to buy kidneys (http://geocities.com/organdonate/religiouscultureandharvesting.html).

The brief discussion of a few religions shows how divergent religious views on transplantations are and how the followers of each faith view transplantations. Yet, what none of them can deny is the constant demand for and shortage of transplantable organs as indicated earlier. One possible way of meeting the demand for transplantable organs is to compensate donors financially. As indicated, people's views on all aspects of organ transplantations are determined, or at least influenced, by religious views. In South Africa Christians and Muslims are the strongest religious groupings. How do they see the practice of rewarding the donor? What are their arguments for or against it? We will firstly discuss some general ideas on financial compensation for donors and then move on to the specific religious views on this topic.

\section{A possible solution to organ shortages: reward the donor financially}

Legislation in South Africa determines that only blood relatives or a spouse may donate an organ while alive. However, unrelated living organ donations have the potential to satisfy the demand, specifically for kidneys.

The reality is that no one, neither a stranger nor a friend, will allow a kidney to be harvested while alive, mainly due to two possible reasons. The administrative process is cumbersome, as Ministerial permission is necessary for such a donation; and secondly, the costs involved are high. When you are hospitalised as a recipient of an organ, your medical aid will cover the costs, but medical aid schemes do not pay for an organ donation. The person giving up a kidney, therefore, has to stand proxy for all medical and hospital 
expenses as well as the medication. On top of these there is time lost at work as well as travelling and accommodation costs. It, therefore, seems necessary and fair to reimburse the donor for the costs incurred by the donation. If this does not happen, black markets will continue. A legalised system of reimbursement, on the other hand, would protect donors against unscrupulous middlemen whose sole interest is to make a profit. A cash-driven donation system has the potential to ensure the safety and dignity of the donors. A paid system may also ease human relationships. People who voluntarily donate an organ to a relative are sometimes subjected to greater coercion than those who received a reward for their organs because of internal pressure from family members to save the loved one. An important obstacle in donating organs as living human beings is the way in which a body is viewed, which gives the removal of an organ a sinister image. The conceptualisation of the body, which is presupposed and necessitated by the transplantation process, is mechanistic and disengaged - constituted of organic parts, not an integral whole (Marshall et al., 1996:5). This is underscored by the rhetoric of donation as "a gift of life". Joralemon (1995:348) concludes that a combination of gift and reward ideologies would perhaps be more effective in suppressing the cultural dismissal of a disembodied "self".

Friedlaender (2002:971-973), an Israeli transplant nephrologist, writes that a few years ago he was adamant that rewarding an organ donor was wrong and would lead to terrible crimes. He admits, however, that he became less emotional since he analysed the situation at renal transplant clinics. He concludes that it is paternalistic to judge a paid kidney donor as poor, ignorant and endangering his health. He now supports legislation which will stipulate that the donor should be rewarded, as he feels it can then be regulated, whereas the present practices cannot (cf. also Slabbert, 2008:7599).

To donate an organ altruistically or to receive a reward for the donation should be a choice made by an autonomous person. The word autonomy ${ }^{7}$ was first used in correlation with states that were selfgoverned. Philosophers adapted this term to be applicable to the rights and interests of individuals. Kant taught that a person has a free will and can, therefore, decide what should be done in specific circumstances, and by implication, he/she is also responsible for

7 Autos $($ Greek $)=$ self; nomos $($ Greek $)=$ rule . 
his/her own actions. In other words, being autonomous means doing as one ought to, as a rational being (Morgan, 2001:87-88).

Respect for a person's autonomy means respect for his/her voluntary choices and can be summarised as follows:

I wish my life and decisions depend on myself, not on external forces of whatever kind. I wish to be the instrument of my own, not of other men's, acts of will. I wish to be a subject, not an object; to be moved by reasons, by conscious purposes, which are my own, not by causes which affect me, as it were, from outside. I wish to be somebody, not nobody: a doer - deciding, not being decided for, self-directed and not acted upon by external nature or by other men as if I were a thing, or an animal or a slave ... I wish, above all, to be conscious of myself as a thinking, willing, active being, bearing responsibility for my choices and able to explain them by references to my own ideas and purposes. (Young, 1998:441.)

Selling organs or rewarding an organ donor is always and everywhere an emotional issue. The views of religious groups on this issue will to a great extent influence how it will be judged. In what follows, we focus on the way the two biggest religious groups might or should view the rewarding of an organ donor. (For a discussion on the general question of the ethics concerning organ selling, cf. Slabbert, 2010.)

\subsection{Christian views on organ donation and the payment of the donor}

With its different denominations 8 and groupings, ${ }^{9}$ Christianity is the worlds' largest religion with a following of about two billion people. Despite the nuanced differences of these denominations and groups, theologically the salvation message is the same: God loved the world so much that He sent his only son, Jesus Christ, that whoever believes in Him should not perish but have life (John 3:16). The ministry of Jesus Christ was about the poor, the sick, the marginalised and the weak (Mark 14:3-9; Luke 4:16-21). According

8 For a list of the different types of Christian denominations, see http://en. wikipedia.org/wiki/List_of_Christian_denominations. Despite these differences, this article will use the word Christian in its generic form except where a particular denomination or group is the focal point.

9 For groups such as the Christian Science Tradition, the Manicheans and the Gnostics, please see May (1985:38-39). 
to the salvation history, his gruesome death on the cross was part of God's salvation plan that Jesus Christ should die for the forgiveness of sins (John 1:26 and Matt. 26:28). This was the ultimate act of altruism (John 17:19).

The Christian religion encourages any act of altruism, including the act of donating an organ whether in life or after death as long as that act does not violate the dignity of the human person. In the same breath, the Christian religion does not look unfavourably on the recipients of a donated organ. Despite the Christian injunction to be altruistic, Christians are still reluctant to donate their organs. Their reluctance to altruistically donate may be attributed to their eschatological view of life. Most, if not all Christian denominations believe in the resurrection, meaning, that death does not mark the final end to one's life. They believe that they will rise one day (Acts 24:16; Cor. 35-44). The reluctance may stem from the fact that they do not want to be incomplete when they rise. This then creates a tension between the desire to want to donate, given the fact that altruism is at the heart of their faith and the fear of what lies ahead, given their eschatological view to life. This tension, we argue, would have been there even if there was not a reward given for the donated organ. It is our argument, therefore, that if this tension is to be mentioned at all, it must be introduced to all debates related to organ donation, even where organs are donated altruistically.

With the supply of altruistically donated organs failing to meet the stubbornly increasing demand, there is growing literature calling for a reward for anyone who donates (Becker \& Elias, 2007:3-22; May, 1985:38-42). Would Christian theology agree with this?

Despite the existence of the World Council of Churches, 10 Christians do not have a central body that acts as a deposit of teachings common to all denominations and groups. The multiplicity of bodies has resulted in nuanced positions on many issues, including the question of receiving reward for organ donations. Unlike altruism, which draws from the very foundation of the Christian faith, reward or incentives for altruism has not received much input from the leadership or theologians of the different denominations. Given the multiplicity of groups who all operate under the Christian umbrella, it therefore becomes difficult to generalise the theological input of one

10 The World Council of Churches is a worldwide ecumenical body that consists of about 349 churches/church groupings who seek to work together. For further reading, see http://www.oikoumene.org 
group over the rest. This being the case, there is some information available from different denominations that provides a basis for understanding what some of the Christian views are to the question of reward or incentives. Two of these will be sampled.

Within the Catholic Church there is a debate on whether the official position of the church endorses acceptance of reward for donating an organ or not. This follows a statement that was made by Pope Pius XII in 1956 in an address to a group of eye specialists that, "[I]t would be going too far to declare immoral every acceptance or every demand of payment. The case is similar to blood transfusions. It is commendable for the donor to refuse recompense, it is not necessarily a fault to accept it." (Capaldi, 2000:141.) These words of the Pope led Capaldi (2000:141) to conclude that the Catholic Church does permit the for-profit sale of human organs for transplantation. Without disputing what the Pope had said, Stempsey (2000:197) argues that Capaldi did not consider the hierarchy of the importance of the different teachings of the Pope. He argues that in the first place, what the Pope said seems to be an almost incidental remark on the sale of organs. To substantiate this point he makes a distinction between the various teachings of the Pope. There are those, he argues, that are extraordinary in nature, and therefore require assent in faith, such as decretal letters. And there are those such as homilies, allocutions, radio and television messages that do not carry more weight. Stempsey (2000:197) places the speech of the Pope in the last category.

The Bible, a central document to all Christian groups, is silent on the matter of receiving a reward for one's altruism. However, the message it gives about human beings created in the image and likeness of God, provides some light about the sacredness of a human person and the dignity it embodies (Gen. 1:26). In this regard, Pope John Paul II (2001:33) stated that,

Accordingly, any procedure which tend to commercialise human organs or to consider them as items of exchange or trade must be considered morally unacceptable, because to use the body as an object is to violate the dignity of the human person.

The concept of human dignity, which in the Christian faith is firmly rooted in the fact that human beings are created in the image and likeness of God and are, therefore, sacred, has further been bolstered by Immanuel Kant's categorical imperative which advocates that one should not treat oneself or others as means to an end (Gill \& Sade, 2002:23-30; Cohen, 2002:44-64). The problem with Kant's 
view is that it would negate even altruistic organ donations on the ground that one is using oneself as a means to an end. The Church of England on the other hand, proscribes the sale of organs on the basis that an organ is a gift, not a commodity (http://www.cofe. anglican.org/news/pr9607.html). Each of the 38 different provinces of the Anglican Communion, however, are independent and not all of them may subscribe to the views of the Church of England (http://en.wikikpedia.org/wiki/Anglican_Communion). This still leaves the question open, like in the case of the Catholic Church, as to what the exact position is.

The question as to whether Christians can accept reward for any organ donation, has not as yet been answered comprehensively. In the absence of a guiding view, individual Christians are left without an authoritative teaching on how to approach the topic of receiving a reward for organ donation.

\subsection{Islamic views on organ donation and the possible financial compensation of donors}

Islam as a religion has its origins in the Arabia of the seventh century. Since then the religion has become a faith with approximately a thousand million followers spread over the earth. In South Africa, Islam has minority status but viewed in the context of Africa, it enjoys a following of about $40 \%$ of the continent's total population (Rossouw et al., 2007:33). The word Islam means peace, but in its religious sense it implies engaged, surrender or submission to God or Allah's will. The belief in Islam involves the acceptance of God's oneness and the prophethood of Muhammad. Muhammad is the recipient of the holy scripture of Islam called the Holy Qur'an (Rossouw et al., 2007:33).

The Qur'an states in many verses that Allah is the one giving life and ending it. The Qur'an is not for or against organ transplantations as such, as it is not addressed directly, but it is reported in a hadith that apparently Allah said: "Breaking the bone of a dead person is equal [in sinfulness and aggression] to breaking it while that person is alive" (Ebrahim \& Haffejee, 1989:13). Because of this writing, some Muslims question the opening up of a person's body to remove organs. But the Shari'ah, the primary source of Islamic law, allows certain actions (although it is against religious interpretations) if it is in the interest of a person, for example an incision can be made on a pregnant woman in order to save the baby (Ebrahim \& Haffejee, 1989:13). Thus, if removed organs can benefit another it is acceptable, but under strict conditions. It must be the only way of 
treating the ailment; the success of the transplantation must be highly probable; the donor or the family must have consented to it; and if possible transplantation must be between Muslims only (Ebrahim \& Haffejee, 1989:16).

Some Muslims also agree with the living donation of a kidney from one Muslim to another because the Qur'an stipulates: "Help you one another in righteousness and piety." The hadith adds:

'The believers, in their love and sympathy for one another, are like a whole body, when one part of it is affected with pain then the whole of it responds in terms of wakefulness and fever' ... 'if one is in need of a certain organ and another has one available would that not be a gesture of altruism, an act of sharing for the benefit of Muslims?' (Ebrahim \& Haffejee, 1989:17.)

The 1981 Islamic Code of Medical Ethics, endorsed by the First International Conference on Islamic Medicine stated that the individual is the collective responsibility of society, which has to ensure his health needs by any means while inflicting no harm on others. This includes the donation of body fluids or organs and is regarded as a fard kifayah, which is a compulsory duty that donors fulfil on behalf of society. The Shariah contains verses which provide support for this. The Qur'an states that "they give priority over themselves even though they are needy". The Prophet Muhammad stated in a hadith (tradition) that "the faithful in their mutual love and compassion are like the body .... if one member complains of an ailment all other members will rally in response". This verse and tradition underline the fact that one of the five fundamental objectives (maqasid) of the Shari'ah is the right to life. Thus, all possible means should be used for treating and saving human life, so long as the means used are legally acceptable and justifiable (Hathout, 1998-1990:114-116).

Hathout (1998-1990:115) concludes by saying that donations between Muslims should be free and voluntarily. Human organs should not be treated as commodities for sale, but if there is a dire need, and purchase of the organ is the only way it can be procured, then it is lawful for the needy buyer (by necessity) although sinful to the seller, unless the latter is extremely needy. He suggests a system of suitable reward should be devised by a government to prevent organ trafficking.

\section{Conclusion}

Although it is possible to determine the views of different religions on organ transplants it is not as easy to determine their stance concern- 
ing a reward to the donor. In the previous sections a few deductions were made from Christian and Islamic principles. Apart from religious concerns in a society based on human rights, personal autonomy should, however, also be honoured. In other words the individual must, after informed consent has been given, be allowed to donate or to accept reward for a donated organ, justified purely on his/her autonomy and personal belief system. Autonomy is doing what is right - not because others think it is right. Because you can justify it through your personally and freely selected and justified view of life, it is exercising control over your own actions in terms of your norms. The risk a donor takes is his/hers, not the physician's or ethicist's. If one decides on an autonomous basis, i.e. freely, rationally and responsibly to donate an organ, the decision should be respected. A decision to accept money for donating an organ should be weighed and treated similarly (Munson, 2007:226).

Marshall et al. (1996:11) advocates a view of "live and let live". If someone chooses to allow the removal of an organ for financial reward, let them; if someone needs money and sells an organ, it benefits him/her and is certainly life-saving for the recipient. Gill and Sade (2002:39) remind all critics who are against rewarding a donor that there is another side to organ transplants: people are waiting for organs, especially kidneys, people who will live if they receive the organ, if not, will die, or at least suffer needlessly. Critics ought, therefore, to consider the complete picture and not only the donor's situation. Also keep in mind that up to now motivating donors to donate altruistically has not succeeded.

\section{List of references}

BECKER, G.S. \& ELIAS, J.J. 2007. Introducing incentives in the market for live and cadaveric organ donations. Journal of economic perspectives, 2(3):322.

BLACKBEARD, M. 2003. Consent to organ transplantation. Tydskrif vir hedendaagse Romeins-Hollandse reg, 66:47-48.

CAPALDI, N.A. 2000. A Catholic perspective on organ sales. Christian bioethics, 60(2):139-151.

CAPLAN, A.K. \& COELHO, D.H. 1998. The ethics of organ transplants: the current debate. Amherst: Prometheus.

COHEN, C.B. 2002. Public policy and the sale of human organs. Kennedy Institute of Ethics journal, 12(1):44-64.

DESAI, P.N. 1988-1990. Hinduism and bioethics in India: a tradition in transition. (In Brody, B., Lustig, B. \& Brody, B., ed. Bioethics yearbook. Vol. 1: Theological developments in bioethics. Houston: The Center for Ethics, Medicine and Public Issues. p. 55-58.)

EBRAHIM, A.F.M. \& HAFFEJEE, A.A. 1989. The Shari'ah and organ transplants. Mobeni: Islamic Medical Association of South Africa. 
FOX, R.C. \& SWAZEY, J.P. 1992. Spare parts: organ replacement in American society. New York: Oxford University Press.

FRIEDLAENDER, M.M. 2002. The right to buy or sell a kidney: are we failing our patients? The Lancet, 359:971-973.

GARWOOD-GOWERS, A. 1999. Living organ transplantation: key legal and ethical issues. Dartmouth: Ashgate.

GHODS, A.J. \& SAVAJ, S. 2006. The Iranian model of paid and regulated living unrelated kidney donation. Clinical journal of the American Society of Nephrology, 1:1136-1145.

GILL, M.B. \& SADE, R.M. 2002. Paying for kidneys: the case against prohibition. Kennedy Institute of Ethics journal, 12(1):17-45.

GOODWIN, M. 2006. Black markets: the supply and demand of body parts. New York: Cambridge University Press.

GUTIERREZ, D. 2009. Singapore to legalize financial compensation for organ donors. http://.naturalnews.com Date of access: 25 Feb. 2010.

HADDOW, G. 2006. "Because you're worth it?" The taking and selling of transplantable organs. Journal of medical ethics, 32:324-328.

HATHOUT, H. 1988-1990. Islamic concepts and bioethics. (In Brody, B., Lustig, B. \& Brody, B., ed. Bioethics yearbook. Vol. 1: Theological developments in bioethics. Houston: The Center for Ethics, Medicine and Public Issues. p. 66-67.)

JOHN PAUL II, Pope. 2001. Special address to the Transplantation Society. Transplant proceedings, 33:31-31.

JORALEMON, D. 1995. Organ wars: the battle for body parts. Medical anthropology quarterly, 9(3):335-356.

KANNIYAKONIL, S. 2009. The promotion of organ donation and transplantation. http://www.lifeissues.net Date of access: 25 Feb. 2010.

KISHORE, R.R. 2005. Human organs, scarcities and sale: morality revisited. Journal of medical ethics, 31:362-365.

LIEBENBERG, D. 2010. Netcare in die pekel: R22 miljoen glo uit onwettige orgaanoorplantings verdien. Beeld: 2, 17 Sept.

MARSHALL, P.A., THOMASMA, D.C. \& DAAR, A.S. 1996. Marketing human organs: the autonomy paradox. Theoretical medicine, 17:1-18.

MAY, W.F. 1985. Religious justification for donating body parts. The Hastings Center report, 15(1):38-42.

MORGAN, D. 2001. Issues in medical law and ethics. London: Cavendish.

MUNSON, R, 2007. Organ transplantation. (In Steinbock, B., ed. The Oxford handbook of bioethics. Oxford: Oxford University Press. p. 211-239.)

OTT, B.B. 1998. Defining and re-defining death. (In Caplan, A.L. \& Coelho, D.H., eds. The ethics of organ transplants: the current debate. Amherst: Prometheus. p. 16-23.)

RADCLIFF-RICHARDS, J. 1991. From him that hath not. (In Land, W. \& Dossetor, J., eds. Organ replacement therapy: ethics, justice and commerce in organ replacement theory. Berlin: Springer Verlag. p. 190191.)

ROSSOUW, D., PROZESKY, M., BURGER, M., DU PLESSIS, C. \& VAN ZYL, M. 2007. Ethics for accountants and auditors. Oxford: Oxford University Press.

ROTH, A.L. Organ donation and compensation in Singapore: new legislation. http://merketdesigner.blogspot.com Date of access: 25 Feb. 2010. 
SIMINOFF, L.A. \& CHILLAG, K. 1999. The fallacy of the "Gift of life". Hastings Center report, 29(6):34-41.

SLABBERT, M. 2008. Combat organ trafficking - reward the donor or regulate sales. Koers, 73(1):75-99.

SLABBERT, M. 2009. This is my kidney, I can do what I want with it - property rights and ownership in human organs. Obiter, 30(3):499-517.

SLABBERT, M. 2010. Ethics, justice and the sale of kidneys for transplantation. PER, 2:xxxx.

SLABBERT, M. \& OOSTHUIZEN, H. 2007a. Establishing a market for human organs in South Africa. Part 1: A proposal. Obiter, 28(1):44-69.

SLABBERT, M. \& OOSTHUIZEN, H. 2007b. Establishing a market for human organs in South Africa. Part 2: Shortcomings in legislation and the current system of organ procurement. Obiter, 28(2):304-323.

SOUTH AFRICA. 1983. Human Tissue Act, 65 of 1983. Pretoria: Government Printer.

SOUTH AFRICA. 2003. National Health Act, 61 of 2003. Pretoria: Government Printer.

SQUE, M. \& PAYNE, S.A. 1996. Dissonant loss: the experience of donor relatives. Social science and medicine, 43(9):1359-1370.

STATZ, S.E. 2006. Finding the winning combination: how blending organ procurement systems used internationally can reduce the organ shortage. Vanderbijl journal of transnational law, 39:1677-1709.

STEMPSEY, W.E. 2000. Organ markets and human dignity: on selling your body and soul. Christian bioethics, 6(2):195-204.

TAYLOR, J.S. 2005. Stakes and kidneys: why markets in human body parts are morally imperative. Aldershot: Ashgate.

VARGA, A.C. 1980. The main issues in bioethics. New York: Ramsey.

YOUNG, R. 1998. Informed consent and patient autonomy. (In Kuhse, H. \& Singer, P., eds. A companion to bioethics. Oxford: Oxford University Press. p. 441.)

\section{Web sites}

http://en.wikipedia.org/wiki/Anglican_Communion Date of access: 7 Sept. 2009. http://en.wikikipedia.org/wiki/List_of_Christian_denominations Date of access: 17 Mar. 2010.

http://www.cofe.anglican.org/nems/pr9607.html Date of access: 25 Feb. 2010. http://www.donatelifenm.org/religiousviews.htm Date of access: 25 Feb. 2010. http://www.geocities.com/organdonate/religioncultureandharvesting.html Date of access: 25 Feb. 2010.

http://www.odf.org.za Date of access: 17 Mar. 2010.

http://www.oikoumene.org Date of access: 17 Mar. 2010.

\section{Court cases}

The State $v$ netcare Kwa-Zulu Natal (pty) Ltd - Agreement in terms of section 105(1) of the Criminal procedure Act 51 of 1977, netcare Kwa-Zulu Natal, Durban - Case No 41/1804/2010 


\section{Key concepts:}

Christian religion

Muslim religion

organ donation

organ transplantation

rewarded gifting

\section{Kernbegrippe:}

Christelike geloof

Moslemgeloof

orgaanoorplantings

orgaanskenking

skenkervergoeding 